\title{
Comparative study of DNA extraction methodologies from goat sperm and its effects on polymerase chain reaction analysis
}

\author{
E.C.B. Silva ${ }^{1}$, M.A. Pelinca ${ }^{1}$, A.C. Acosta ${ }^{2}$, D.M.F. Silva ${ }^{3}$, \\ M.A. Gomes Filho ${ }^{3}$ and M.M.P. Guerra ${ }^{1}$
${ }^{1}$ Laboratório de Andrologia, Departamento de Medicina Veterinária, Universidade Federal Rural de Pernambuco, Recife, PE, Brasil ${ }^{2}$ Laboratório de Doenças Infecto-Contagiosas, Departamento de Medicina Veterinária, Universidade Federal Rural de Pernambuco, Recife, PE, Brasil ${ }^{3}$ Laboratório de Fisiologia e Morfologia Animal, Departamento de Morfologia e Fisiologia Animal, Universidade Federal Rural de Pernambuco, Recife, PE, Brasil

Corresponding author: E.C.B. Silva

E-mail: silva.ecb@gmail.com

Genet. Mol. Res. 13 (3): 6070-6078 (2014)

Received June 24, 2013

Accepted January 22, 2014

Published August 7, 2014

DOI http://dx.doi.org/10.4238/2014.August.7.21

\begin{abstract}
Successful DNA extraction is indispensable for molecular methods based on polymerase chain reaction (PCR); however, goat sperm DNA extraction is limited. Thus, the aim of this study was to evaluate three methods to extract DNA from goat sperm for use in PCR. Eight goat semen pools were used for DNA extraction by using the DNeasy Blood \& Tissue Kit, phenol-chloroform, and Chelex-100 methods. DNA samples were analyzed spectrophotometrically to determine the DNA concentration and purity, visualized on $0.8 \%$ agarose gel, and used at different amounts $(150,100,50,10$, and 1 ng) for PCR with electrophoresis, followed by $1.5 \%$ agarose gel electrophoresis. The quantity of DNA extracted with Chelex-100 was
\end{abstract}


higher $(\mathrm{P}<0.05)$ than that obtained with either the DNeasy Blood \& Tissue Kit or the phenol-chloroform method, with the phenolchloroform method yielding a greater quantity $(\mathrm{P}<0.05)$ than the kit. The DNeasy Blood \& Tissue Kit produced a higher $(\mathrm{P}<0.05)$ purity product than the Chelex-100 method, and all samples obtained by the three protocols were positive for DNA, as assessed by electrophoresis. All of the different concentrations of DNA produced by these methods were amplified by PCR, although for DNA produced by the phenolchloroform method, PCR was only possible after complementary purification. In conclusion, the Chelex-100 method is cheap, secure, simple, fast, and effective, and is a potential tool for extracting goat sperm DNA without limitations in PCR.

Key words: DNA extraction; Goat; PCR; Semen

\section{INTRODUCTION}

The polymerase chain reaction (PCR) revolutionized the field of molecular genetics because it is a relatively fast, easy, and sensitive technique that permits fast amplification and in vitro analysis of specific DNA sequences (Koch and Andrade, 2008). PCR is frequently used in clinical diagnostics (Masri et al., 1997; Manterola et al., 2003; Grom et al., 2006; Sharifzadeh et al., 2011), animal breeding programs (Lien et al., 1993; Coelho et al., 2004; Milazzotto et al., 2008), progeny tests, determination of sex ratios in samples where X-bearing and Y-bearing sperm are separated (Resende et al., 2009), and in forensic science (Hanson and Ballantyne, 2004; von Wurmb-Schwark et al., 2006; Koch and Andrade, 2008).

Despite its wide applicability, the success of the PCR method depends on the quality and quantity of the DNA template (Coelho et al., 2004; von Wurmb-Schwark et al., 2006), which should be free of contaminants and DNA nucleases that impair the amplification process (Manuja et al., 2010). There are many methods currently available for DNA purification; however, problems related to contamination with foreign DNA, PCR inhibitors, and DNA susceptibility to fragmentation still persist (Coelho et al., 2004).

Commercial kits offer quick, easy, and efficient methods for extracting DNA (Moore et al., 2004), although these kits can also be expensive (Aidar and Line, 2007; Bailes et al., 2007). Consequently, it is common to use classical procedures for the purification of DNA that employ the organic solvent phenol-chloroform (Santella, 2006). On the other hand, the phenol-chloroform method is labor-intensive (Goldenberger et al., 1995; Santella, 2006), based on the use of toxic substances (Fernandes et al., 2004; Karthikeyan et al., 2010), and can result in PCR inhibition by the compounds used for extraction (Goldenberger et al., 1995). By contrast, a Chelex-based protocol is a fast, practical, and effective method for extracting DNA of high quality (Giraffa et al., 2000) and with low contamination (Boom et al., 1990), which does not involve organic solvents (Walsh et al., 1991).

However, mammalian tissues exhibit considerable variation in their structures; therefore, one DNA extraction technique might not be suitable for all tissue types (Hossain et al., 1997). Sperm cells present a high degree of nuclear compaction by protamines (Griffin, 2013) and a strong nuclear membrane (Horsman et al., 2005), which inhibits the extraction of sperm 
DNA by standard techniques used for somatic cells (Hossain et al., 1997; Griffin, 2013), as observed in goat sperm DNA extractions (Silva et al., 2011). Thus, the aim of this study was to evaluate three methods to extract goat sperm DNA that can be used successfully in PCR.

\section{MATERIAL AND METHODS}

Except when indicated, all reagents used in this experiment were obtained from the Sigma-Aldrich Company (St. Louis, MO, USA).

\section{Semen samples}

Semen samples were collected eight times, on alternating days, from five mature goats using an artificial vagina (located at $08^{\circ} 03^{\prime} 14^{\prime \prime} \mathrm{S} ; 34^{\circ} 52^{\prime} 52^{\prime \prime} \mathrm{W}$ ). One ejaculate from each of the five bucks was pooled at each collection time to eliminate individual variation, producing a total of eight pooled samples, which were aliquoted into microcentrifuge tubes and stored at $-20^{\circ} \mathrm{C}$ until use. The experiments received approval from the Ethics Committee for Animal Experimentation of the Universidade Federal Rural de Pernambuco (Brazil) under process number CEEUA/UFRPE 014/2012.

\section{DNA extraction}

After thawing, each pool of goat semen was divided into three aliquots, and DNA was extracted using the following extraction methods.

\section{Method 1}

DNA was isolated from $100 \mu \mathrm{L}$ semen using the DNeasy Blood \& Tissue Kit (QIAGEN $\mathrm{GmbH}$, Hilden, Germany), according to manufacturer recommendations, and the resulting samples were stored at $-20^{\circ} \mathrm{C}$ until use.

\section{Method 2}

Total DNA was extracted with phenol-chloroform, according to Hanson and Ballantyne (2004) with small modifications. One hundred microliter semen aliquots were centrifuged at $6000 \mathrm{rpm}$ for $5 \mathrm{~min}$. Each pellet was resuspended in $1 \mathrm{~mL}$ TES solution [100 mM Tris-HCl, $\mathrm{pH}$ 8.0, $100 \mathrm{mM} \mathrm{NaCl}, 1 \mathrm{mM}$ ethylenediaminetetraacetic acid (EDTA)] and centrifuged again. To each pellet, $500 \mu \mathrm{L}$ lysis buffer $[10 \mathrm{mM}$ Tris- $\mathrm{HCl}, \mathrm{pH} 8.0,100 \mathrm{mM} \mathrm{NaCl}, 25$ mM EDTA, $0.5 \%$ sodium dodecyl sulfate (SDS)] was added, along with $22 \mu \mathrm{L} 0.1 \mathrm{M}$ dithiothreitol (DTT) and $25 \mu \mathrm{L}$ proteinase $\mathrm{K}$ (QIAGEN GmbH). The mixture was incubated at $55^{\circ} \mathrm{C}$ for $3 \mathrm{~h}$, with hourly vortexing, after which $500 \mu \mathrm{L}$ phenol, equilibrated with Tris, $\mathrm{pH} 7.8$, was added, followed by vortexing and centrifugation at 10,000 rpm for $3 \mathrm{~min}$. The supernatant was transferred to another tube, together with $300 \mu \mathrm{L}$ phenol and $300 \mu \mathrm{L}$ chloroform, followed by vortexing and centrifugation at 10,000 rpm for $3 \mathrm{~min}$. The supernatant was transferred to a new tube, and then $700 \mu \mathrm{L}$ chloroform was added. The mixture was vortexed and centrifuged again, and the supernatant was transferred to another tube. Two volumes of cold $95 \%$ ethanol 
were added, and the tube was incubated at $-20^{\circ} \mathrm{C}$ for $4 \mathrm{~h}$. Each sample was centrifuged at $10,000 \mathrm{rpm}$ for $10 \mathrm{~min}$, and the supernatant was subsequently removed. Each DNA pellet was dried, resuspended in $50 \mu \mathrm{L} 1 \mathrm{X}$ TE buffer (100 mM Tris-HCl, $\mathrm{pH}$ 7.5, 0.25 M EDTA), and stored at $-20^{\circ} \mathrm{C}$ until use.

\section{Method 3}

DNA was extracted using the Chelex-100 method as described by Manuja et al. (2010). A $25-\mu \mathrm{L}$ semen sample aliquot was added to $200 \mu \mathrm{L} 5 \%$ Chelex-100, with the subsequent addition of $5 \mu \mathrm{L}$ proteinase K (QIAGEN GmbH) and $31 \mathrm{mM}$ DTT. The mixture was vortexed, incubated at $56^{\circ} \mathrm{C}$ for $45 \mathrm{~min}$, and boiled in a water bath for $8 \mathrm{~min}$ to inactivate proteinase $\mathrm{K}$. After vigorous vortexing for $10 \mathrm{~s}$, the sample was centrifuged at 10,444 rpm for $3 \mathrm{~min}$, and the supernatant was collected and stored in a new tube at $-20^{\circ} \mathrm{C}$ until use.

\section{Concentration and purity of DNA}

The genomic DNA concentration and purity were assessed by optical density measurements in a BioMate 3 spectrophotometer (Thermo Scientific, Holtsville, NY, USA). For this purpose, DNA absorbance was measured at $260 \mathrm{~nm}$ to determine the quantity of DNA, and DNA purity was estimated by determining the $\mathrm{A}_{260} / \mathrm{A}_{280}$ ratio and comparing it to the reference value 1.8 (Santella, 2006).

\section{DNA visualization on agarose gel}

The presence and quality of genomic DNA extracted by the three methods was analyzed on $0.8 \%$ agarose gel. Five microliter sperm DNA aliquots were stained with 0.3 $\mu \mathrm{L}$ Blue-Green (LGC Biotecnologia, Cotia, SP, Brazil) and submitted to electrophoresis on the agarose gel. The result was visualized under an ultraviolet (UV) transilluminator (Vilber Lourmat, Paris, France), and the image was digitalized (C7070; Olympus, Tokyo, Japan).

\section{DNA amplification}

Genomic DNA was amplified by PCR using primers specific for the Capra hircus GAPDH gene (GenBank No. AJ431207), according to Celestino et al. (2010), using different DNA amounts: $150,100,50,10$, or $1 \mathrm{ng}$. The PCR mix contained $1.5 \mathrm{U}$ Taq DNA polymerase, $2.5 \mu \mathrm{L} 10 \mathrm{X}$ Taq buffer with $\mathrm{KCl}, 0.16 \mathrm{mM}$ dNTP, $2 \mathrm{mM} \mathrm{MgCl}_{2}, 5 \mathrm{pM}$ of each GAPDH primer (forward: 5'-TGTTTGTGATGGGCGTGAACCA-3' and reverse: 5'ATGGCGTGGACAGTGGTCATAA-3'), different DNA concentrations, and sterile ultrapure MilliQ water to a final volume of $25 \mu \mathrm{L}$.

Amplification was performed using a MultiGene Thermocycler (Labnet International Inc.; Edison, NY, USA), and a PCR program consisting of denaturation at $95^{\circ} \mathrm{C}$ for $5 \mathrm{~min} ; 35$ cycles of amplification involving denaturation at $95^{\circ} \mathrm{C}$ for $30 \mathrm{~s}$, annealing at $65^{\circ} \mathrm{C}$ for $1 \mathrm{~min}$, and extension at $75^{\circ} \mathrm{C}$ for $40 \mathrm{~s}$; and a final extension for $10 \mathrm{~min}$ at $72^{\circ} \mathrm{C}$. The success of the PCR with different DNA concentrations from the three extraction protocols was determined by electrophoresis on $1.5 \%$ agarose gel. For this analysis, $5 \mu \mathrm{L}$ amplified sperm DNA was 
stained with $3 \mu \mathrm{L}$ Blue-Green, visualized under UV transillumination after electrophoresis, and the image was digitalized.

\section{Statistical analysis}

The DNA concentration and purity values were statistically evaluated by analysis of variance (ANOVA), and differences were compared with the post hoc Tukey test at a significance level of 0.05 . The results are reported as means $\pm \mathrm{SD}$.

\section{RESULTS}

The quantity and purity of the DNA obtained by the three extraction methods are shown in Table 1. The spectrometric assay demonstrated that the quantity of DNA extracted from sperm samples was higher $(\mathrm{P}<0.05)$ for the Chelex-100 protocol than for the DNeasy Blood $\&$ Tissue Kit or phenol-chloroform methods, although the yield for the latter was greater $(\mathrm{P}<$ $0.05)$ than for the kit. The DNeasy Blood \& Tissue Kit gave a higher $(\mathrm{P}<0.05)$ mean DNA purity than did Chelex-100. The kit and the phenol-chloroform protocols yielded purities of nearly 1.8 , although there was variation among the samples extracted with kit. DNA was observed on $0.8 \%$ agarose gel in all eight samples extracted with the three protocols tested (Figure 1).

Table 1. Concentration $(\mathrm{ng} / \mu \mathrm{L})$ and purity $\left(\mathrm{A}_{260} / \mathrm{A}_{280}\right)$ of goat sperm genomic DNA according to each method tested.

\begin{tabular}{|c|c|c|c|c|c|c|}
\hline \multirow[t]{2}{*}{ Samples } & \multicolumn{2}{|c|}{ DNeasy Blood \& Tissue Kit $(100 \mu \mathrm{L})$} & \multicolumn{2}{|c|}{ Phenol-chloroform $(100 \mu \mathrm{L})$} & \multicolumn{2}{|c|}{ Chelex-100 $(25 \mu \mathrm{L})$} \\
\hline & Quantity & Purity & Quantity & Purity & Quantity & Purity \\
\hline 1 & 25.82 & 1.75 & 125.70 & 1.71 & 369.70 & 1.03 \\
\hline 2 & 85.25 & 1.25 & 154.90 & 1.67 & 295.80 & 0.92 \\
\hline 3 & 53.90 & 4.00 & 175.00 & 1.50 & 412.50 & 1.02 \\
\hline 4 & 80.80 & 1.60 & 132.40 & 1.63 & 249.75 & 0.87 \\
\hline 5 & 51.58 & 1.48 & 132.50 & 1.63 & 569.80 & 1.19 \\
\hline 6 & 60.63 & 2.50 & 156.05 & 1.81 & 321.65 & 0.96 \\
\hline 7 & 13.50 & 0.00 & 197.50 & 1.54 & 289.10 & 0.97 \\
\hline 8 & 53.90 & 4.00 & 153.75 & 1.55 & 260.95 & 0.90 \\
\hline Mean & 53.17 & 2.07 & 153.48 & 1.63 & 346.16 & 0.98 \\
\hline$\pm \mathrm{SD}$ & $24.42^{\mathrm{A}}$ & $1.38^{\mathrm{a}}$ & $24.10^{\mathrm{B}}$ & $0.10^{\mathrm{a}, \mathrm{b}}$ & $105.50^{\mathrm{C}}$ & $0.10^{\mathrm{b}}$ \\
\hline
\end{tabular}

$\overline{A, B, C}$ Within quantity columns, values with different superscripts were significantly different $(\mathrm{P}<0.05)$ in genomic DNA concentration; ${ }^{a, b}$ within purity columns, values with different superscripts were significantly different $(\mathrm{P}<$ $0.05)$ in genomic DNA purity. The numbers within parenthesis represent the initial semen sample used for each DNA extraction method.

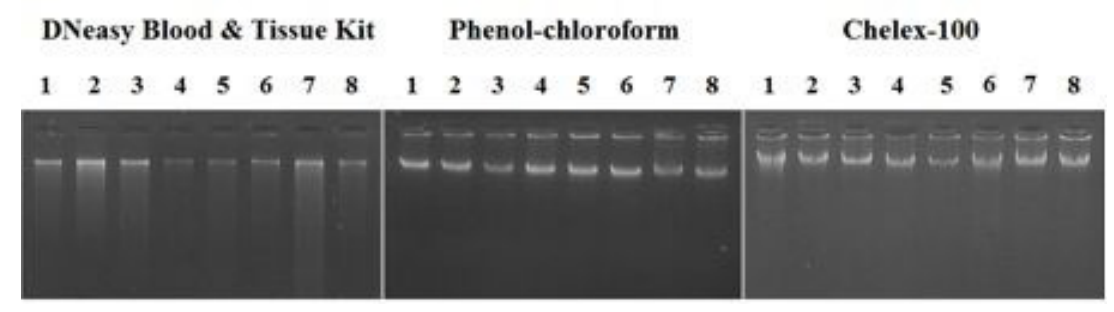

Figure 1. Electrophoresis results on $0.8 \%$ agarose gel with DNA extracted from eight semen samples (1-8) by using the DNeasy Blood \& Tissue Kit, phenol-chloroform, and Chelex-100 methods. 
The 154-bp fragment of the C. hircus GAPDH gene was amplified from the DNA samples isolated with the DNeasy Blood \& Tissue Kit and the Chelex-100 method, but for the phenol-chloroform-isolated samples, PCR was only possible after complementary DNA purification with 24:1 chloroform:isoamyl alcohol (Figure 2). All samples treated with the DNeasy Blood \& Tissue Kit and the Chelex-100 method formed specific bands after PCR and electrophoresis on $1.5 \%$ agarose gel for all DNA amounts used $(150,100,50,10$, or $1 \mathrm{ng})$; bands were also observed for phenol-chloroform-treated samples, except for sample eight with 1 ng DNA.

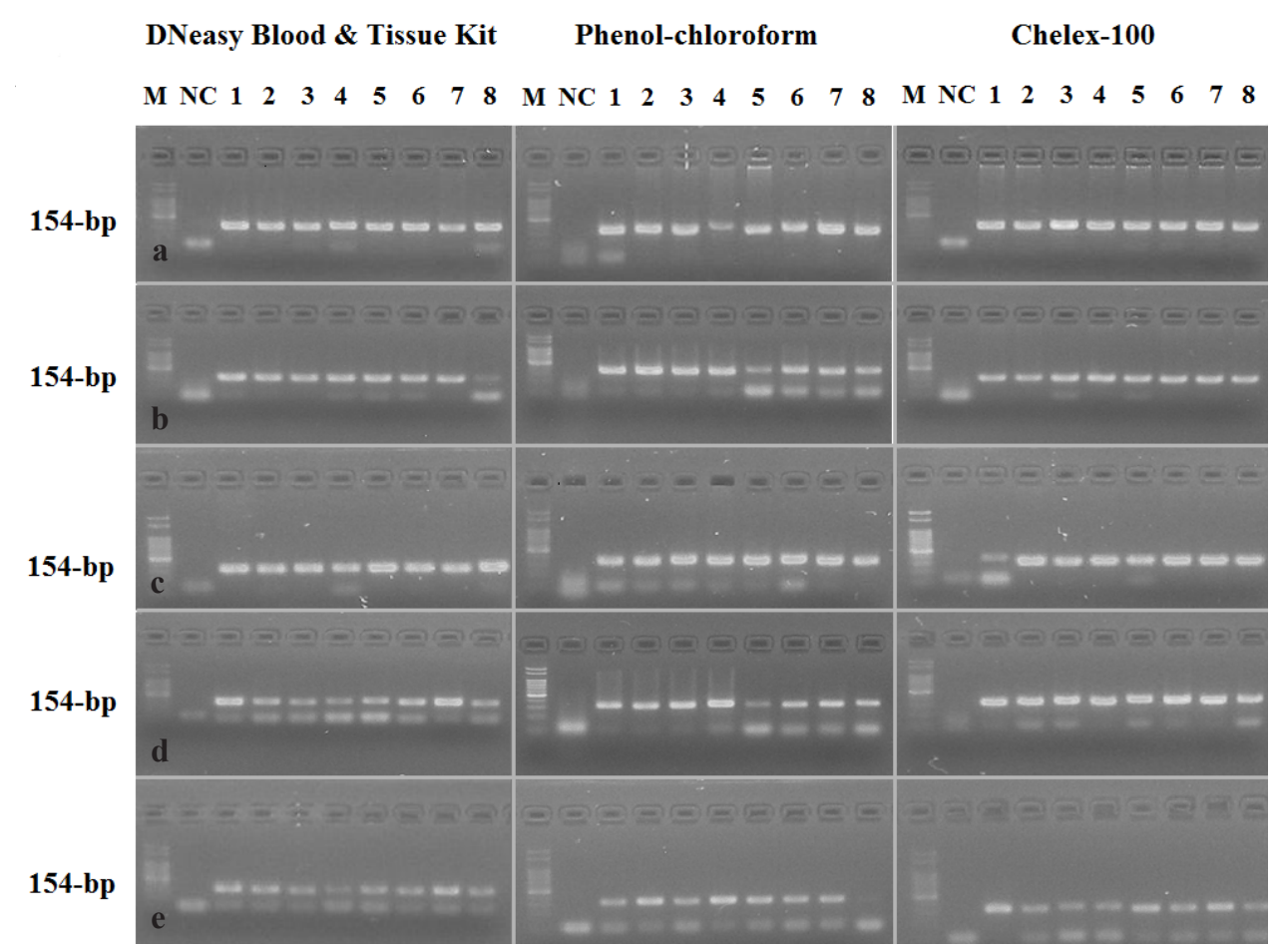

Figure 2. PCR products obtained by $1.5 \%$ agarose gel electrophoresis, amplified using Capra hircus GAPDH primers, and $150 \mathrm{ng}(\mathbf{a}), 100 \mathrm{ng}(\mathbf{b}), 50 \mathrm{ng}(\mathbf{c}), 10 \mathrm{ng}(\mathbf{d})$, and $1 \mathrm{ng}$ (e) DNA extracted from eight pools of semen samples (1-8) by the DNeasy Blood \& Tissue Kit, phenol-chloroform, and Chelex-100 methods. Lane M=50-bp marker ladder; lane $N C=$ negative control.

\section{DISCUSSION}

DNA extraction is one of the most common procedures used in genetics, molecular biology, and biochemistry (Yang et al., 2008). Thus, a good DNA extraction protocol should be fast, practical, cheap, free of contamination and toxicity, and produce DNA of high quantity and quality to be used in PCR (Barea et al., 2004; Aidar and Line, 2007) with minimal fragmentation (Yang et al., 2008). However, many conventional DNA extraction protocols do not have these characteristics (Goldenberger et al., 1995), thus limiting their usefulness for producing DNA templates for PCR (Coelho et al., 2004; Manuja et al., 2010). 
In the present study, we found that the wide use of the DNeasy Blood \& Tissue Kit is not justified based on results of the spectrophotometric assay, which showed low DNA concentrations. Furthermore, the purity of DNA isolated by the kit varied from 0.0 to 4.0, representing values below and above the ideal of 1.8 (pure DNA), which reflect contamination by protein and RNA, respectively (Santella, 2006).

Similarly, extraction with Chelex-100, although yielding high DNA concentration values, produced a DNA purity below 1.8. On the other hand, the chloroform protocol yielded the highest concentration and purity values, ranging from 125.70 to $197.50 \mathrm{ng} / \mu \mathrm{L}$ and from 1.50 to 1.81 , respectively. Therefore, it is likely that increased exposure time to proteinase $\mathrm{K}$ (Mesquita et al., 2001) and treatment with RNase (Manuja et al., 2010) may reduce DNA contamination by proteins and RNA, respectively, in samples purified by both the DNeasy Blood \& Tissue Kit and Chelex-100.

Despite variability in the data obtained from the spectrophotometric assay, all methods of extraction presented positive evidence of DNA after electrophoresis, with little variation in the quality of bands formed. However, there was no PCR amplification of DNA extracted using the phenol-chloroform protocol for all DNA concentrations used unless an additional purification step with chloroform-isoamyl alcohol was performed. This fact was also observed by Barea et al. (2004), who showed the generation of PCR inhibitory substances by organic solvents. Moreover, the use of a low SDS detergent concentration $(0.001 \%)$ in the phenol-chloroform procedure may act as an inhibitor of Taq polymerase in PCR (Goldenberger et al., 1995).

After purification of DNA extracted with phenol-chloroform, PCR products were visible, with uniform band formation after 1.5\% agarose gel electrophoresis. However, it is clear that the use of the DNeasy Blood \& Tissue Kit is limited by its high cost (Bailes et al., 2007), and extraction with phenol-chloroform is a laborious and potentially hazardous method (Sepp et al., 1994), where a significant amount of DNA can be lost (Goldenberger et al., 1995) and degraded (Hossain et al., 1997) and the PCR inhibited (Goldenberger et al., 1995).

By contrast, Chelex-100 resin emerged as a cheap, effective, fast, and simple method, which can be realized in few steps, and does not require the use of organic solvents, which confirms observations of previous studies (Walsh et al., 1991; Simonato et al., 2007). The Chelex-100 method results in a low risk of sample contamination (Boom et al., 1990; Walsh et al., 1991; Simonato et al., 2007) and a lower hazard to the technician and the environment (Fernandes et al., 2004; Karthikeyan et al., 2010).

Moreover, Chelex-100 chelates polyvalent metal ions, which may act in the breakdown of DNA and PCR inhibition (Sepp et al., 1994; Barea et al., 2004). As this protocol only requires a low sample volume $(25 \mu \mathrm{L})$ (Manuja et al., 2006), it can be applicable to situations where the quantity of biological material is limited, for example, in forensic assays (Koch and Andrade, 2008; Walsh et al., 1991).

In conclusion, the Chelex-100 method emerged as cheap, secure, simple, fast, and effective, and is therefore a potential tool for extracting sperm DNA without limitations for PCR.

\section{ACKNOWLEDGMENTS}

The authors are grateful to the Brazilian funding agencies Fundação de Amparo à Ciência e Tecnologia do Estado de Pernambuco (FACEPE) and Conselho Nacional de Desenvolvimento Científico e Tecnológico (CNPq). 


\section{REFERENCES}

Aidar M and Line SR (2007). A simple and cost-effective protocol for DNA isolation from buccal epithelial cells. Braz. Dent. J. 18: 148-152.

Bailes SM, Devers JJ, Kirby JD and Rhoads DD (2007). An inexpensive, simple protocol for DNA isolation from blood for high-throughput genotyping by polymerase chain reaction or restriction endonuclease digestion. Poult. Sci. 86: 102-106.

Barea JA, Pardini MIMC and Gushiken T (2004). Extração de DNA de materiais de arquivo e fontes escassas para utilização em reação de polimerização em cadeia (PCR). Rev. Bras. Hematol. Hemoter. 26: 274-281.

Boom R, Sol CJ, Salimans MM, Jansen CL, et al. (1990). Rapid and simple method for purification of nucleic acids. $J$. Clin. Microbiol. 28: 495-503.

Celestino JJ, Bruno JB, Lima-Verde IB, Matos MH, et al. (2010). Steady-state level of kit ligand mRNA in goat ovaries and the role of kit ligand in preantral follicle survival and growth in vitro. Mol. Reprod. Dev. 77: 231-240.

Coelho EGA, Oliveira DAA, Teixeira CS and Sampaio IBM (2004). Comparação entre métodos de estocagem de DNA extraído de amostras de sangue, sêmen e pêlo e entre técnicas de extração. Arq. Bras. Med. Vet. Zoot. 56: 111-115.

Fernandes JV, Meissner RV, Fernandes TAAM and Rocha LRM (2004). Comparação de três protocolos de extração de DNA a partir de tecido ficado em formol e incluído em parafina. J. Bras. Patol. Med. Lab. 40: 141-146.

Giraffa G, Rossetti L and Neviani E (2000). An evaluation of chelex-based DNA purification protocols for the typing of lactic acid bacteria. J. Microbiol. Methods 42: 175-184.

Goldenberger D, Perschil I, Ritzler M and Altwegg M (1995). A simple "universal” DNA extraction procedure using SDS and proteinase $\mathrm{K}$ is compatible with direct PCR amplification. PCR Methods Appl. 4: 368-370.

Griffin J (2013). Methods of sperm DNA extraction for genetic and epigenetic studies. Methods Mol. Biol. 927: 379-384.

Grom J, Hostnik P, Toplak I and Barlic-Maganja D (2006). Molecular detection of BHV-1 in artificially inoculated semen and in the semen of a latently infected bull treated with dexamethasone. Vet. J. 171: 539-544.

Hanson EK and Ballantyne J (2004). A highly discriminating 21 locus Y-STR "megaplex" system designed to augment the minimal haplotype loci for forensic casework. J. Forensic. Sci. 49: 40-51.

Horsman KM, Barker SL, Ferrance JP, Forrest KA, et al. (2005). Separation of sperm and epithelial cells in a microfabricated device: potential application to forensic analysis of sexual assault evidence. Anal. Chem. 77: 742-749.

Hossain AM, Rizk B, Behzadian A and Thorneycroft IH (1997). Modified guanidinium thiocyanate method for human sperm DNA isolation. Mol. Hum. Reprod. 3: 953-956.

Karthikeyan V, Patharajan S, Palani P and Spadaro D (2010). Modified simple protocol for efficient fungal DNA extraction highly suitable for PCR based molecular methods. GJMS 5: 37-42.

Koch A and Andrade FM (2008). A utilização de técnicas de biologia molecular na genética forense: uma revisão. Rev. Bras. Anal. Clin. 40: 17-23.

Lien S, Kaminski S, Aleström P and Rogne S (1993). A simple and powerful method for linkage analysis by amplification of DNA from single sperm cells. Genomics 16: 41-44.

Manterola L, Tejero-Garcés A, Ficapal A, Shopayeva G, et al. (2003). Evaluation of a PCR test for the diagnosis of Brucella ovis infection in semen samples from rams. Vet. Microbiol. 92: 65-72.

Manuja A, Prasad M, Kumar B and Prasad G (2006). Molecular detection of BHV-1 genome in semen of buffalo (Bubalus bubalis) bulls. Ind. Buffalo 4: 8-11.

Manuja A, Manchanda S, Kumar B and Khanna S (2010). Evaluation of different methods of DNA extraction from semen of buffalo (Bubalus bubalis) bulls. Buffalo Bull. 29: 109-128.

Masri SA, Nguyen PT, Gale SP, Howard CJ, et al. (1997). A polymerase chain reaction assay for the detection of Leptospira spp. in bovine semen. Can. J. Vet. Res. 61: 15-20.

Mesquita RA, Anzai EK, Oliveira RN and Nunes FD (2001). Avaliação de três métodos de extração de DNA de material parafinado para amplificação de DNA genômico pela técnica da PCR. Pesqui. Odontol. Bras. 15: 314-319.

Milazzotto MP, Visintin JA and Assumpção MEOd'A (2008). Biotenologias da reprodução animal: biologia molecular aplicada à biotecnologia. Cienc. Vet. Trop. 11: 145-148.

Moore E, Arnscheidt A, Krüger A and Strömpl C (2004). Simplified Protocols for the Preparation of Genomic DNA From Bacterial Cultures. In: Molecular Microbial Ecology Manual (Kowalchuk GA, Bruijn FJ de, Head IM and Akkermans AD, eds.). 2nd edn. Kluwer Academic Publishers, Dordrecht, 3-18.

Resende MV, Bezerra MB, Perecin F and Almeida AO (2009). Separation of X-bearing bovine sperm by centrifugation in continuous percoll and optiprep density gradient: effect in sperm viability and in vitro embryo production. Cienc. Anim. Bras. 10: 581-587.

Santella RM (2006). Approaches to DNA/RNA extraction and whole genome amplification. Cancer Epidemiol. 
Biomarkers Prev. 15: 1585-1587.

Sepp R, Szabo I, Uda H and Sakamoto H (1994). Rapid techniques for DNA extraction from routinely processed archival tissue for use in PCR. J. Clin. Pathol. 47: 318-323.

Sharifzadeh A, Doosti A and Dehkordi PG (2011). Molecular detection of Bovine leukemia virus (BLV) in the semen samples of bulls. World J. Zool. 6: 285-290.

Silva ECB, Silva DMF, Arruda LCP and Gomes WA (2011). Padronização das Concentrações Espermáticas Para a Extração de DNA. Abstracts of the 19th Congresso Brasileiro de Reprodução Animal, Recife.

Simonato LE, Garcia JF, Nunes CM and Miyahara GI (2007). Avaliação de dois métodos de extração de DNA de material parafinado para aplicação em PCR. J. Bras. Patol. Med. Lab. 43: 121-127.

von Wurmb-Schwark N, Malyusz V, Fremdt H, Koch C, et al. (2006). Fast and simple DNA extraction from saliva and sperm cells obtained from the skin or isolated from swabs. Leg. Med. 8: 177-181.

Walsh PS, Metzger DA and Higuchi R (1991). Chelex 100 as a medium for simple extraction of DNA for PCR-based typing from forensic material. Biotechniques 10: 506-513.

Yang JL, Wang MS, Cheng AC, Pan KC, et al. (2008). A simple and rapid method for extracting bacterial DNA from intestinal microflora for ERIC-PCR detection. World J. Gastroenterol. 14: 2872-2876. 